\title{
Non-Metastatic Childhood Soft Tissue
} Sarcoma

National Cancer Institute

\section{Source}

National Cancer Institute. Non-Metastatic Childhood Soft Tissue Sarcoma. NCI

Thesaurus. Code C115292.

Soft tissue sarcoma that occurs during childhood and is confined to the site in which it initially manifested. 